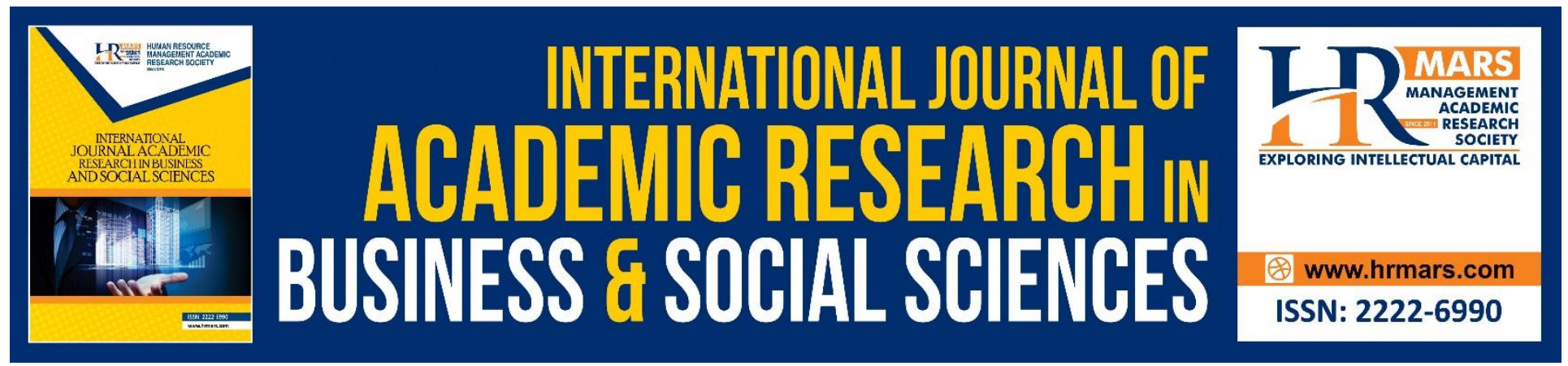

\title{
Syariah Subject Using Integrated Dini Curriculum: A Renewal in Government Aided Educational Religious School
}

\section{Firdaus bt Abdul Fatah, Khadijah Abdul Razak and Maimun Aqsha Lubis}

To Link this Article: http://dx.doi.org/10.6007/IJARBSS/v9-i2/5664 DOI: $10.6007 /$ IJARBSS/v9-i2/5664

Received: 02 Feb 2019, Revised: 21 Feb 2019, Accepted: 08 March 2019

Published Online: 12 March 2019

In-Text Citation: (Fatah, Razak, \& Lubis, 2019)

To Cite this Article: Fatah, F. bt A., Razak, K. A., \& Lubis, M. A. (2019). Syariah Subject Using Integrated Dini Curriculum: A Renewal in Government Aided Educational Religious School. International Journal of Academic Research in Business and Social Sciences, 9(2), 1068-1077.

Copyright: (C) 2019 The Author(s)

Published by Human Resource Management Academic Research Society (www.hrmars.com)

This article is published under the Creative Commons Attribution (CC BY 4.0) license. Anyone may reproduce, distribute, translate and create derivative works of this article (for both commercial and non-commercial purposes), subject to full attribution to the original publication and authors. The full terms of this license may be seen at: http://creativecommons.org/licences/by/4.0/legalcode

Vol. 9, No. 2, 2019, Pg. 1068 - 1077

http://hrmars.com/index.php/pages/detail/IJARBSS

JOURNAL HOMEPAGE

Full Terms \& Conditions of access and use can be found at http://hrmars.com/index.php/pages/detail/publication-ethics 


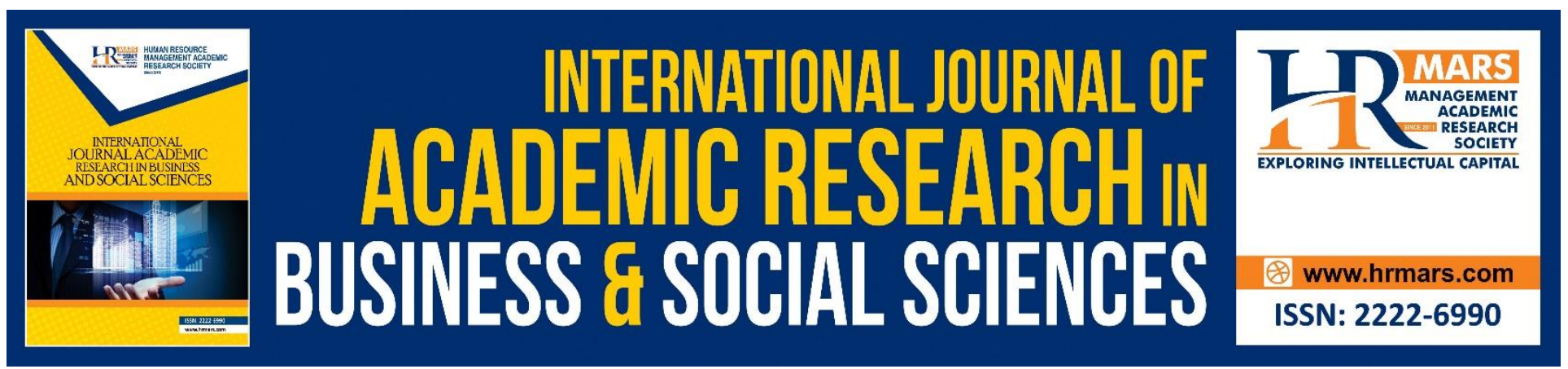

\title{
Syariah Subject Using Integrated Dini Curriculum: A Renewal in Government Aided Educational Religious School
}

\author{
Firdaus bt Abdul Fatah", Khadijah Abdul Razak ${ }^{2}$ and Maimun Aqsha \\ Lubis $^{3}$ \\ ${ }^{1} \mathrm{PhD}$ Candidate, Faculty of Education, Universiti Kebangsaan Malaysia \\ Email: firdausABF@gmail.com \\ ${ }^{2}$ Senior Lecturer, Fakulti of Education, Universiti Kebangsaan Malaysia \\ ${ }^{3}$ Senior Lecturer, Faculty of Education, Universiti Kebangsaan Malaysia
}

\begin{abstract}
Malaysia has multiple school streams. As a matter of fact, one of the streams which is the religious education, has started even before the independence of this country and has undergone various evolutions. Currently, there are Sekolah Agama Bantuan Kerajaan ('SABK' or ilterally transleted as 'Government-aided educational Religious Schools ') in Malaysia. This type of schools is religious education schools for secondary schools' students. The SABK consists of the People's Religious School ('SAR' or Sekolah Agama Rakyat) and the State Religious School ('SAN' or Sekolah Agama Negeri) that are registered under the Ministry of Education. Starting in 2015, SABK has begun to implement a new curriculum known as Integrated Dini Curriculum ('KBD' or Kurikulum Bersepadu Dini). One of the subjects offered in this curriculum is Syariah. The Syariah subject in the new curriculum is an enhancement from the previously used in the curriculum for SAR and SAN. This article aims to discuss the reforms applied to this subject. This study is a conceptual paper that uses qualitative methods based on library resources and other sources relevant to the writing. Findings of this study can be used as a guide to studies related to the Integrated Dini Curriculum.
\end{abstract}

Keywords: Government-Aided Educational Religious School, Integrated Dini Curriculum, Syariah, Sabk, Education.

\section{Introduction}

Education in Islamic religion is a continuous process of producing Muslim individuals who have a personal, spiritual, and eminent character. According to Ina Fauzia (2015), the definition of Islamic education is divided into six definitions, namely al-Tarbiyyah al-Din (Religious education), al-Ta'lim fi 
al-Islam (teaching about Islam), Tarbiyyah al-Muslimin (Teaching of Muslims), al-Tarbiyyah fi al-Islam (Education in Islam), al-Tarbiyyah 'inda Muslimin (Education among Muslims), and al-Tarbiyyah alIslamiyyah (Islamic Education). From the definitions, it can be concluded that Islamic education is aimed at drawing the servants closer to Allah SWT and can be achieved through the teaching of the nature of faith in Allah SWT, morals, worship, fiqah, the Qur'an, the Islamic history, as well as science and technology (Wahyudi, 2011).

\section{Government -Aided Educational Religious School}

The establishment of the Government -Aided Educational Religious School comprises the People's Religious School (SAR) or the State Religious Secondary School (SAN) which are registered under the Ministry of Education (KPM). The development of the Government-Aided Educational Religious School is closely linked to the history of religious school development in Malaya as early as in the 18th century.

In the 18th century, a type of religious school known as sekolah pondok was developed. It grew productively till the end of $19^{\text {th }}$ century, up to the point where some sekolah pondok ended up providing education and shelter to the senior citizens till they decease. (Ministry of Education, 1992). This cottage education system is informal and it focuses only on matters relating to the field of Islamic religion solely without emphasis on academic studies and certificates. Later on, as graduates from the middle-east returned to the country, they-significantly contributed towards the evolvement of these schools into madrasahs. The madrasah school system is more systematic because it involves religious and academic fields and there are certificates that recognize the program (Mohd Hairuddin and Kamarul Azmi, 2012). These schools were established due to the funding or donations and requests from the local communities. This is in line with the study by (Abdul Hafiz, Zakaria Stapa, Ahmad Munawar 2012) that the existence of religious schools arises from the demands of the people who want religious oriented schools and at the same time focusing attentively at the academic aspects. These schools are registered under the Religious School Controlled Enactment (Enakmen Pengawalan Sekolah Agama) and administered by the School Organizing Board ('LPS' or Lembaga Pengelola Sekolah) (Nor Raudhah et al, 2018). Basically, these schools were originally the People's Religious Schools (SAR).

While, the State Religious Schools (SAN) managed by the State Government or the State Islamic Religious Department or the State Education Department or the State Islamic Religious Council or State Government Foundation. These school are registered under the Enakmen Pengawalan Sekolah-Sekolah Agama and administered wholly by the state's religious authority. The registration of SAR and SAN as Government Aid Religious Schools (SABK) is an effort to raise the dignity and empowerment of religious schools in Malaysia in enabling the schools to receive various facilities to improve administrative management, quality of teaching and learning , quality of human resource management and infrastructure as these schools are in the education mainstream under the supervision of KPM and School Board.

\section{Integrated Dini Curriculum (KBD)}

As previously stated, SAR and SAN use the Azhari curriculum. The implementation of the al-Azhari curriculum is not considered a national curriculum. It is designed with different purposes and goals. 
However, this curriculum has been practiced in religious schools along with the National Curriculum. Azhari curriculum consists of several subjects. For instance, a group of subjects in Islamic studies, Arabic Language and literature, with the Arabic Language as the medium of instructions, following the Ma'ahad Bu'uth al-Azhar curriculum model in Egypt (Azizi et.al ,2012). However, the Buu'th Azhari curriculum system is not integrated among schools that practice it (Maimun, Zaffi \& Hanis , 2014)

Thus, to overcome this problem, in 2015 the government introduced a national curriculum for all schools which registered as Government -Aided Educational Religious School (SABK) known as Integrated Dini Curriculum (KBD). Integrated Dini Curriculum is the merger of the Azhari Curriculum that has been coordinated with the existing National Curriculum in the mainstream.

KBD is an effort to enhance the students' abilities to meet the aspirations of pupils in Malaysian Education Development (PPPM). This curriculum will develop the potential of students in religious and Arabic studies because this language has been the language of the dispatcher in teaching and learning (KPM, 2015). It came from the proposal of the Special Committee of Tan Sri Murad in August 2004 and a combination of the Buu'th Azhari curriculum implemented by each state. KBD is co-ordinated with the National curriculum and developed on the basis of the members of the Sunnah al-Jama'ah and taking into account the opinion of Shafi'e Mazhab (KPM, 2015).

KBD subjects use Arabic as the medium of instructions. Generally, there are some changes in this curriculum in terms of the distribution of religious subjects and assessments. Religious subjects in the (KBD) include Usul al-din, Al-Syariah and Al-Lughatul Arabiah al Muasirah compared to Azhari curriculum that offers more religious subjects namely Nahu Sorof, Tafsir, Tauhid, Figh,al- Hadith, AlQuran, Insya' and Sirah. (Rohaida, M.Aderi \& Maimun , 2016). In terms of assessment, KBD is assessed through school-based assessments and is recognized in Malaysian Certificate subjects while Azhari is assessed through a special religious certificate during Form 4 and 6. KBD also brings changes to the minimum time allocation for a teaching week and provide consistent textbooks supplied by the Malaysian Ministry of Education (KPM,2015).

\section{Syariah Subject in Malaysia Education Curriculum}

In the Malaysian education system, at the primary and lower level secondary schools, there is actually no specific subject known as Syariah. Normally syariah-related matters are taught in Islamic Education (Pendidikan Islam) subject. At the primary level, all students will study Tilawah Al-Quran, Ulum Syariah, Akhlak and Jawi as part of Islamic Education subject.

While at the lower secondary level, Syariah subject is also still not isolated from Islamic Education (Pendidikan Islam) subject. At this stage, the key areas in Islamic Education (Pendidikan Islam) subject are the Learning of the Qur'an and Hadith, Syariah Learning and Syariah based on Akhlak Islamiah.

At the upper secondary level, started in 1992, the syariah knowledge is specifically introduced as a subject known as the Islamic Syariah Education (PSI or Pendidikan Syariah Islamiah) as part of Kurikulum Bersepadu Sekolah Menengah (KBSM). However, it is only an elective subject in one of the four elective groups offered for students taking SPM (KPM 1991)

At this stage, there is a textbook prepared by the Ministry of Education. It was compiled based on the Integrated High School Curriculum (KBSM) and was certified by the Ministry of Education Malaysia 
(KPM). This textbook met the syllabus and the syllabus description provided by several departments of the Ministry of Education such as the Curriculum Development Center, Islamic and Moral Education Department and the Technical Education Department (Abdul Halim \& Nur Hanani, 2015).

For the STPM level, Islamic Syariah education is a continuation of the Islamic Knowledge for High School, Paper One subject in the curriculum used prior to KBSM, but in terms of educational content there is an addition to the part of the Verses and Ahkam Hadith (BPK 1991). Subsequently, when the Integrated Dini Curriculum (KBD) was introduced in 2015, one of the subjects in the curriculum was Syariah Islamiah.

\section{Renewal of Syariah Subject in Integrated Dini Curriculum}

The Syariah subjects offered in the Integrated Dini Curriculum cover two areas namely the alQuran wa al-Hifz and Fiqh. In the Quranic field wa al-Hifz, the syllabus covers the reading of the quality of the Quran with the correct 'linguistic al-gebra' which covers surah and the meaning of the chosen words and the whole surah al-Mulk, Yaasin, al-Sejadah, al-Insan with the whole meaning .Meanwhile, the syllabus in the field of figh includes figh ibadat, fiqh munakahat, fiqh muamalat and fiqh jinayat (KPM, 2015).

The combination of Al-quran wal Hifz in syariah subjects distinguishes the subdivision of the subjects in the Azhari curriculum. Therefore, the Quran and Fiqh in Azhari curriculum are considered as separate subjects (Zetty \& Halim, 2014). The combination of Al-Quran wal-Hifz and feqah in one subject coincides with Imam al-Ghazali's view on Shari'ah knowledge, which is the origin of knowledge such as the al-Qur'an. Understanding the verses of the good Qur'an will facilitate the problem solving (Zaydan,2006). This combination is also profound because the Qur'an and al-Sunah are the main sources of law in Islam as the Almighty Allah says:

"It is He Who has sent down to you the Book. In it are verses that are entirely clear, they are the foundations of the Book; and others not entirely clear. So as for those in whose hearts there is a deviation (from the truth) they follow (only) that which is not entirely clear thereof, seeking Al-Fitnah, and seeking its $T a^{\prime}$ 'wil, but none knows its $T a^{\prime}$ wil except Allah. And those who are firmly grounded in knowledge say: "We believe in it; all of it is from our Lord." And none receive admonition except men of understanding".

(Ali Imran:7)

In addition, Syariah subjects in KBD curriculum is more focused and is rated in accordance with the progress of the students. Title distribution can be seen in table 1.1. In Form 1, students are taught about taharah and matters related to fardu prayers, emphasizing on prayers is the most vital thing as it instills the concept of devotion and the relationship between servants and God and forms good individuality. (Muhammadiah, 1982) in return fulfilling the objectives of the KBD curriculum. Although taharah and basic prayers have been taught during the primary school level, teaching should continue well into the students because children who are educated from childhood ritual would easily practise when reaching puberty and implement it continuously (Suwayd, 2000). 
Munakahat, which is a knowledge related to marriage is taught in Form 3, as compared to being introduced in Form 4 in Azhari curriculum through Fiqh subject and PSI subject. It is perceived as being necessary to be introduced in the syllabus as early as in Form 3 due to the common moral degradation relating to teenagers nowadays (Suraya,2018). These teenagers are mostly involved in severe social problems regarding promiscuity, adultery and the dumping of illegitimate babies. This exposure to such knowledge about marriage is consistent with the study by Kamarul (2017). He reckoned that teenagers should be given early guidelines of the compulsory and forbidden conduct. This is relevant as preventive measures to ensure teenagers are conserving their dignity and selfworth against sexual activities and as such.

As being discussed earlier, all subjects including Syariah are being taught in Arabic. Therefore, to enhance students' mastery in Arabic, KBD stresses on reading skills (qiraah) and writing (kitabah) . This focus is executed in Form 1 and 2 through al-Lughatul al -Arabiah Mu'aisirah (KPM, 2015). The stress on these two skills are essential because the ability to master the skills will improve the students' attitude towards Arabic itself, (Muhamad, Ahmad, Mat, 2013), in which being used in all subjects of this curriculum. KBD Syariah subject is also taught by well-qualified teachers who are of Azhari teachers. They are also among Islamic Education and Arabic teachers who are trained by the Ministry of Education. These teachers who are already teaching in school, are the masters of the skills in Dini subjects. They are definitely competent and capable in conducting the teaching and learning process in Arabic. The mastery in Arabic among teachers who teach Syariah subject will ensure the content of the lessons and learning objectives are achieved as stated in the study by Wan Azura (2007) that communication skills are important in mastering Arabic. 
INTERNATIONAL JOURNAL OF ACADEMIC RESEARCH IN BUSINESS AND SOCIAL SCIENCES

Vol. 9, No. 2, Feb, 2019, E-ISSN: 2222-6990 @ 2019 HRMARS

Tablel 1.1 Distribution for KBD AI-Syariah subjects

\begin{tabular}{|c|c|c|c|c|c|}
\hline Form & $\begin{array}{l}\text { Al-Quran Wa Al- } \\
\text { Hifz }\end{array}$ & Fiqh Al-Ibadat & Fiqh Munakahat & Fiqh Muamalat & Fiqh Jinayat \\
\hline Form 1 & $\begin{array}{l}\text { - Listening to } \\
\text { mahkraj } \\
\text { hijaiyyah letters } \\
\text { and practice. } \\
\text { - Reading,underst } \\
\text { anding and } \\
\text { memorizing of } \\
\text { Surah al-Naas to } \\
\text { Surah al-Syams }\end{array}$ & $\begin{array}{l}\text { - } \text { Cleansing } \\
\text { - Vindicating faeces. } \\
\text { - Istinjak. } \\
\text { - } \text { Ablutions. } \\
\text { - Bathe } \\
\text { - Tayammum. } \\
\text { - Menstrual, } \\
\text { Childbed bleeding } \\
\text { (Nifas) dan } \\
\text { Istihadah. } \\
\text { - Prayers }\end{array}$ & & & \\
\hline Form 2 & $\begin{array}{l}\text { - Reading and } \\
\text { memorizing } \\
\text { Surah } \\
\text { Al-Mitoffifin, } \\
\text { Surah al-Insyiqaq, } \\
\text { Al-Buruj, al-Tariq, } \\
\text { Al- a'la, al- } \\
\text { Ghasyiah, A-Fajr, } \\
\text { Al-Balad }\end{array}$ & $\begin{array}{l}\text { - Jumu'ah Prayer } \\
\text { - Jumu'ah Sermons } \\
\text { - Guidelines in } \\
\text { performing prayers } \\
\text { for a sick person } \\
\text { - Eclipse sunnah } \\
\text { - } \text { prayer } \\
\text { - Tahiyatib prayer } \\
\text { - } \text { Iktikaf } \\
\text { - Tahajjud prayer } \\
\text { - Witr prayer }\end{array}$ & & & \\
\hline Form 3 & $\begin{array}{l}\text { - Reading } \\
\text { and memorizing } \\
\text { Surah An-Nisa', Al- } \\
\text { Naaziat, Abasa, Al- } \\
\text { Takathur, Al- } \\
\text { Infithar }\end{array}$ & $\begin{array}{l}\text { - } \text { Fasting in } \\
\text { - Ramadhan } \\
\text { - Qada', Fidyah, } \\
\text { Fasting Kafarah } \\
\text { - Tarawih prayer } \\
\text { - Eid prayers } \\
\text { - Dhuha prayer } \\
\text { - Qasar prayer } \\
\text { - Jama' prayer } \\
\text { - Managing the } \\
\text { deceased }\end{array}$ & $\begin{array}{l}\text { - Family in Islam } \\
\text { - Engagement } \\
\text { - Solemnization } \\
\text { - Engagement } \\
\text { - The rights of } \\
\text { husband and } \\
\text { wife } \\
\text { - Nusyuz }\end{array}$ & $\begin{array}{l}\text { - Muamalat in } \\
\text { Islam } \\
\text { - al-Riba } \\
\text { - al-Gharar } \\
\text { - al-Tadlis } \\
\text { - al- } \\
\text { Muqamarah }\end{array}$ & \\
\hline Form 4 & $\begin{array}{l}\text { - Reading and } \\
\text { rememorizing } \\
\text { Surah al-Mulk } \\
\text { and Yassin }\end{array}$ & $\begin{array}{l}\text { - } \text { al-Istisqa prayer; } \\
\text { - Masnunah prayer } \\
\text { - } \text { Muharramah } \\
\text { - } \text { prayer } \\
\text { - al-Makruhah prayer } \\
\text { - Zakat al-fitr } \\
\text { - Zakat al-amwal }\end{array}$ & $\begin{array}{l}\text { - Divorce } \\
\text { - Fasakh } \\
\text { - aKhulu' } \\
\text { - Effect after } \\
\text { divorce } \\
\text { - Poligamy }\end{array}$ & $\begin{array}{l}\text { - Akad al- } \\
\text { muawadat } \\
\text { - Akad al- } \\
\text { tabbaru'at }\end{array}$ & \\
\hline
\end{tabular}


INTERNATIONAL JOURNAL OF ACADEMIC RESEARCH IN BUSINESS AND SOCIAL SCIENCES Vol. 9, No. 2, Feb, 2019, E-ISSN: $2222-6990$ ๑ 2019 HRMARS

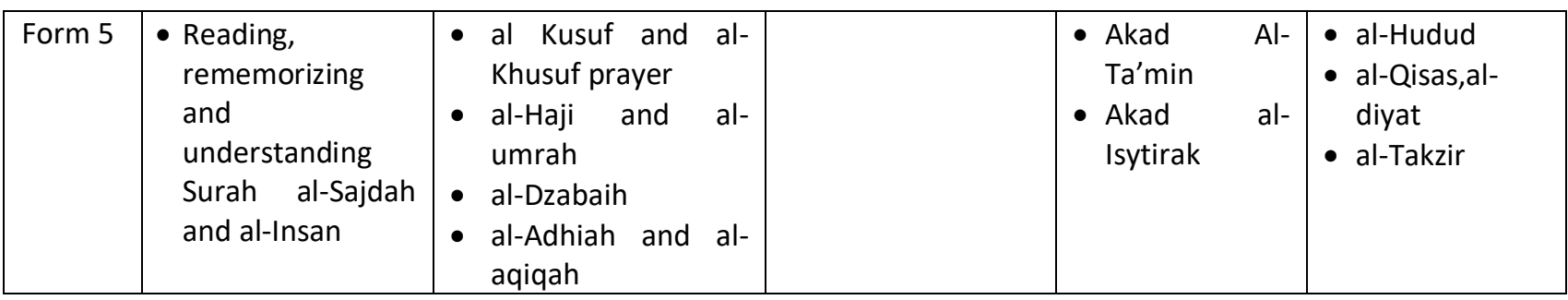

The Syariah KBD curriculum also recommends that teachers teach using the 21st century learning methods. Teachers are encouraged to emphasize thinking and learning skills as well as life skills and career based activities in order to produce students who are able to compete globally. The use of $21^{\text {st }}$ century teaching methods in this subject will help to boost the students' motivation in exploring the content being discussed in the subject. Besides, the mastery of $21^{\text {st }}$ century skills will involve more student-centred activities. Hence, preparing the students to be capable of fulfilling the current global needs and uplifting students 'personal skills. (Ainun, Zamri, Wan Muna ,2017).

Due to these subjects has become a national curriculum, so it provided a textbook. This textbook is provided by the Textbook Division of the Ministry of Education Malaysia and is uniformly used by all KBD schools as opposed to textbooks during the Azhari curriculum. The contents of KBD Syariah textbooks are more student-friendly because their contents are more organized,and participate with graphics and QR codes (Suraya, 2018). However, (Kamarulzaman, Ahmad Sabri \& Nik Mohd Rahimi, 2017) found that complex sentence levels in KBD textbooks are higher than simple sentences. The suitability of the reading language and the readability of readers are the aspects is important in ensuring that readers understand what is read (Badgett, 2010).

\section{Conclusion}

In conclusion, the Syariah subjects in KBD have been carefully crafted to achieve their goal of creating a knowledgeable, believing, righteous, righteous, virtuous, skillful in al-Quran and al-Sunah and contributing to enhancing the nation's-and nation's civilization as well as the well-being of nature to achieve the happiness of the world and the hereafter. However, the contents of this subject are processed in order to be more structured and appropriate to Malaysia which takes into account the views of the Members of the al-Sunnah wal Jama'ah and the view of the Shafi'e Mazhab.

\section{Corresponding Author}

Firdaus bt. Abdul Fatah, firdausABF@gmaill.com , Faculty of Education, Universiti Kebangsaan Malaysia, 43600 UKM, Bangi , Selangor, Malaysia

\section{References}

Abu, M.H., Ali, M. J., \& Khairul, M. Y. (2001). Management Accounting. Journal of Accounting, 42(1), 234-245.

Ahmad, W. A. W. (2007). Pendekatan dan strategi efektif dalam penguasaan bahasa Arab. Bandar Baru Nilai: Penerbit Universiti Sains Islam Malaysia. 
INTERNATIONAL JOURNAL OF ACADEMIC RESEARCH IN BUSINESS AND SOCIAL SCIENCES

Vol. 9, No. 2, Feb, 2019, E-ISSN: $2222-6990$ ๑ 2019 HRMARS

Amin, M. H., \& Jasmi K.A., (2012). Sekolah agama di Malaysia: sejarah, isu \& cabaran. Penerbit UTM Press.

Badgett, B. A. (2010). Toward the development of a model to estimate the readability of credentialing - examination materials. Tesis PhD, University of Nevada, Las Vegas

http://www.recitequran.com/tafsir/en.ibn-kathir/3:200 retrieved 15.12.2018

Ghani, K. A., Noh, A. S., \& Yusuff, N. M. R. N. (2017). Ciri-Ciri Linguistik dalam Buku Teks Berbahasa Arab dan Hubungannya dengan Tahap Kebolehbacaan Teks di Malaysia (Linguistic Features of Arabic Textbooks and its Correlation with Text Readability Level in Malaysia). GEMA Online ${ }^{\circledR}$ Journal of Language Studies, 17(3).

Iberahim, A. R., Mahamod, Z., \& Mohammad, W. M. R. W. (2017). Pembelajaran Abad Ke-21 Dan Pengaruhnya Terhadap Sikap, Motivasi Dan Pencapaian Bahasa Melayu Pelajar Sekolah Menengah (21th Century Learning and the Influence of Attitude, Motivation and Achievements Malay Language Secondary School Student). Jurnal Pendidikan Bahasa Melayu, 7(2), 77-88.

Fauzia, I. (2015). Prinsip dan Ajaran Islam dalam Ilmu Pengetahuan. Retrieved 1.10.2018, 2018, from http://inafauzia95.blogspot.my/2015/05/prinsip-dan-ajaran-islam-dalam-ipteks.htm

Ismail, M., Wan Maizatul A.W.A., and Azman C. M., (2013). Sikap dan realiti penguasaan kemahiran bahasa Arab pelajar program j-QAF. GEMA Online ${ }^{\circledR}$ Journal of Language Studies, 13.(2) ,81-97

Jaafar, M. (1982). Beberapa Aspek Pendidikan Islam. Surabaya: Penerbit al-Ikhlas.

Kementerian Pendidikan Malaysia (1991). Surat Pekeliling Ikhtisas Bil. 6/1991 : Sukatan Pelajaran dan Peruntukan Masa Untuk Mata-Mata Pelajaran Program Kurikulum Bersepadu Sekolah Menengah (KBSM) Bagi Sekolah Menengah Rendah Dan Sekolah Menengah Atas.

Kementerian Pendidikan Malaysia (2015) Maklumat Asas Pelaksanaan Kurikulum Bersepadu Dini. Purtajaya: BPI.

Lubis, M. A., Alias, Z., \& Shaharudin, H. N. (2014). Pelaksanaan Pengajaran dan Pembelajaran Bahasa Arab dalam Kurikulum Bu'uth Al-Azhar di Sekolah Agama Bantuan Kerajaan (SABK)(The Implementation of Teaching and Learning Arabic Based on Bu'uth Al-Azhar Curriculum in Sekolah Agama Bantuan Kerajaan (SABK). Jurnal Pendidikan Malaysia (Malaysian Journal of Education), 39(1), 51-61.

Nik, R. A., Che Noh, M. A.\& Lubis M.A.,(2018). Kurikulum Bersepadu Dini Di Sekolah Bantuan Agama Kerajaan Sebagai Satu Kurikulum Kebangsaan: Pelaksanaan dan Cabaran, Proceeding The $11^{\text {th }}$ International Workshop And Conference Of Asean Studies in Linguistics, Islamic and Arabic Education, Social Sciences and Educational Technology, 220-228

Siren, N. R. H., Azmi, I.A. G., Jalil, S. J. B. A., \& Ab Majid, A. (2018). Kepelbagaian Pengurusan Sekolah Agama Rakyat Di Malaysia. Journal of Al-Tamaddun, 13(1). Pg 45-56 doi.org/10.22452/JAT

Suraiya Selamat. Ketua Panitia Mata pelajaran Syariah KBD, SAM Pasir Panjang8. Temubual pada 20 September 2018.

Tamuri, A. H., \& Husin, N. H., (2017) Pendidikan Abad ke 21 Dalam Kepelbagaian Budaya: Cabaran dan Harapan , key note speaker Seminar Pedagogi Antarabangsa ke-8 (PEDA8).

Tuah, A. H. M., Stapa, Z., \& Munawar, A. (2012). Memperkasakan Jati Diri Melayu-Muslim Menerusi Pendidikan Islam Dalam Pengajaran Akhlak (Strengthening Malay-Muslim Identity through Islamic Education and Akhlak Teaching)." Jurnal Hadhari: An International Journal, 23-35. 
INTERNATIONAL JOURNAL OF ACADEMIC RESEARCH IN BUSINESS AND SOCIAL SCIENCES

Vol. 9, No. 2, Feb, 2019, E-ISSN: $2222-6990$ ๑ 2019 HRMARS

Umar, A., Jamsari, E. A. , Kasan, H., Hassan, W. Z., Basir, A., \& Azizi, A.A., (2012). The Challenges Of Producing Islamic Scholars Via Al-Azhar Curriculum In Religious Schools In The Malaysian National Education System. Advances in Natural and Applied Sciences, 6(7), 1036-1043.

Zaydan, 'A. K., (2006). al-Wajiz Fi Usul al-Fiqh. Beirut: Muassasah al-Risalah Nasyirun. 